Izr. prof. dr. Sabina

Jelenc Krašovec

Filozofska fakulteta

Univerze $v$ Ljubljani

\title{
ANDRAGOŠKO SVETOVALNO DELO - KLJUČ DO USPEŠNEGA IZOBRAŽEVANJA ODRASLIH
}

\section{POVZETEK}

Andragoško svetovalno delo (ASD) lahko razumemo kot pomemben vezni člen v izobraževanju odraslih, saj z ustrezno dostopnostjo do svetovalnih dejavnosti in njihovim kakovostnim izvajanjem pomembno pripomore $k$ vključevanju vseh, tudi ranljivih skupin odraslih v učni in izobraževalni proces. Ponudba in izvajanje informacijskih in svetovalnih dejavnosti se razlikujeta glede na to, kdo svetovalno delo ponuja in s kakšnim namenom ter cilji, kje se to izvaja, katerim skupinam odraslih je namenjeno, katere zvrsti prevladujejo, pa tudi glede na to, kdo svetovalne dejavnosti financira. Zahtevnejše zvrsti ASD lahko izvajajo le posebej usposobljeni svetovalci, sicer pa pri svetovalnem delu sodelujejo tudi drugi strokovnjaki, ki pri svojem siceršnjem delu le uporabljajo veščine svetovanja, ter prostovoljci.

Ključne besede: andragoški svetovalci, (manjkajoči) vezni člen, zvrsti andragoškega svetovalnega dela, ugotavljanje potreb po andragoškem svetovalnem delu.

\section{COUNSELLING IN ADULT EDUCATION - THE KEY TO SUCCESSFUL ADULT EDUCATION - ABSTRACT}

Counselling can be seen as an important (missing) link in adult education, since appropriate access to guidance and provision of quality counselling services can significantly contribute to inclusion of all groups of adults into the process of learning and education, including the most vulnerable. The range and provision of information and guidance activities varies depending on a number of factors, such as who performs them, what aims and goals are pursued, where the activities are conducted, which segments of adults they cater for, which activities are predominant, and also who sponsors the activity. The more demanding categories of counselling can be undertaken only by specially trained counsellors; however, professionals in different fields who employ counselling skills in their own work can, besides volunteers, also provide educational guidance for adults.

Keywords: counsellors in adult education, (missing) link, activities/categories of educational guidance for adults, needs assessment in educational guidance for adults.

UDK: 374.7

\section{UVOD}

V sodobni družbi se zaradi spremenjenih zahtev pomembno spreminja tudi ponudba izobraževanja odraslih, ki lahko poteka v ustanovah za izobraževanje odraslih in mladih kot tudi na drugih mestih in v drugih ustanovah, ki niso izrecno namenjene izobraževanju, kot so delovne organizacije, prostovoljske organizacije, knjižnice, društva, bolnišnice, različni domovi in še marsikje drugje. Ta pestrost izhaja iz raznolikih potreb odraslih v različnih življenjskih obdobjih, njiho- vih interesov, povezanih z vsakdanjim življenjem in delom, iz potrebe po reševanju problemov $\mathrm{v}$ delovanju posameznika v družbeni skupnosti. V izobraževanje odraslih se torej vključujejo odrasli različnih starosti, ras, etnične pripadnosti, življenjskih slogov, kulturnih izkušenj, vloga izobraževalnih dejavnosti pa naj bi bila tudi korekcija družbenih problemov, kot so brezposelnost, neenakost, rasizem, homofobija, nepismenost, seksizem, revščina, izključenost (Edwards, Armstrong, Miller, 2001; Moore, 2004). 
Cilji izobraževanja odraslih niso enoznačni, temveč jih lahko razvrstimo vsaj v štiri sklope. Izredno pomembna vloga izobraževanja odraslih je, da poskuša izenačevati možnosti dostopa do izobraževanja in možnosti doseganja enakih rezultatov med različnimi skupinami odraslih. $\mathrm{K}$ temu pripomore tudi boljši dostop do svetovalne pomoči, tako pred vključitvijo v izobraževanje kot tudi med izobraževanjem. Drugi pomembni cilj je krepitev pojavnosti neformalnega izobraževanja, kar povečuje sposobnosti državljanov za dejavno udeležbo pri razvoju družbe. Pri tem imamo v mislih nediskriminatorne izobraževalne prakse, ki spodbujajo vzajemni dialog med učečimi se in prispevajo h kritičnemu ozaveščanju ljudi (Foley, 2004). Sem sodijo denimo skupnostno izobraževanje, medgeneracijsko izobraževanje in tudi sicer vse izobraževanje, ki ni povezano z delom in zaposlitvijo. Pomemben cilj izobraževanja odraslih je tudi zadovoljevanje posameznikove individualne potrebe po znanju, pri tem pa ni pomembno, na podlagi česa njegove potrebe nastajajo; lahko so bodisi posledica neuspešnosti v začetnem izobraževanju bodisi izvirajo zgolj iz njegovih osebnih interesov in vedoželjnosti. Zadnji, a v današnjem času najbolj poudarjen in politično pomemben cilj pa je izobraževanje in usposabljanje za delo in poklic. Izobraževanje odraslih je ta čas postalo ključni politični dejavnik razvoja delovne sile in ekonomskega gibanja $\mathrm{v}$ družbi, kar je pomembno pripomoglo $\mathrm{k}$ temu, da je izobraževanje odraslih pridobilo prepoznavnejšo vlogo v socialnih, ekonomskih in družbenih politikah (Illeris, 2004).

Ob ponudbi raznolikih programov izobraževanja odraslih je treba zagotoviti ustrezne podporne dejavnosti, med katere sodi tudi andragoško svetovalno delo. Ponudba in izvajanje informacijskih in svetovalnih dejavnosti se lahko razlikujeta glede na to, kdo svetovalno delo ponuja in kje se izvaja, katere zvrsti prevladujejo, glede na to, katerim skupinam odraslih je svetovalna dejavnost namenjena, kdo jo financira in kakšni so cilji svetovalne pomoči.

\section{KDO JE ANDRAGOŠKI SVETO- VALEC IN KDO VSE UPORABLJA VEŠČINE ANDRAGOŠKEGA SVETOVANJA?}

V raziskavi ALPINE (2008) so strokovnjake, ki delujejo na področju izobraževanja odraslih, glede na dejavnosti in vloge, ki jih opravljajo, razdelili v več skupin: poučevanje, vodenje in organiziranje izobraževalnega procesa, svetovalno delo, načrtovanje in razvoj izobraževalnih programov, tehnična in organizacijska ter medijska podpora, ki jo izvajajo v učnem procesu. Informiranje, nasvetovanje in svetovanje se torej omenjajo kot posebno pomembne dejavnosti, ki jih izvajajo andragoški delavci; kako bodo te dejavnosti izvajali, pa je seveda odvisno od več dejavnikov (od tega, ali gre za splošno, poklicno, formalno ali neformalno izobraževanje odraslih; od potreb, možnosti in želja različnih skupnosti in organizacij; od sistemskih možnosti celotnega področja izobraževanja odraslih v neki državi; od razvitosti področja izobraževanja odraslih itd.).

Za področje svetovalnega dela različni avtorji (Howard, 1996; Woolfe, 1997; Egan, 1994; Lawton, 2008 idr.) ugotavljajo, da imamo na eni strani (bolj ali manj) usposobljene svetovalce, ${ }^{1}$ katerih osnovna dejavnost je svetovalno delo odraslim, na drugi strani pa obstaja ogromno število drugih strokovnjakov, ki delajo na področju izobraževanja, socialnega skrbstva, zdravstva, prostovoljskih in skupnostnih dejavnosti itd., ki pri svojem delu bolj ali manj pogosto uporabljajo veščine svetovanja, vendar se ne imenujejo svetovalci. Gerard Egan različne strokovnjake, ki tako ali drugače sodelujejo v procesu pomoči, imenuje formalne in neformalne »pomagače« (Egan, 1994: 4), pri čemer prvi delujejo $\mathrm{v}$ ustanovah $\mathrm{z}$ izrecnim namenom svetovanja in pomoči tistim, ki to potrebujejo, drugi pa so strokovnjaki na svojem področju, vendar se ob svojem delu srečujejo tudi s potrebo po pomoči ljudem. Zlahka se strinjamo z njegovo ugotovitvijo, 
da odrasli le manjši del svetovalne pomoči dobijo od profesionalnih svetovalcev, večino pa od drugih strokovnjakov, pa tudi od povsem »laičnih svetovalcev«, kot lahko imenujemo prijatelje, sorodnike, znance in druge ljudi, ki nam pomagajo reševati vsakodnevne težave. To velja tudi za vprašanja, povezana $\mathrm{z}$ izobraževanjem, kjer tudi naše raziskave kažejo, da se ljudje pogosto obrnejo na svoje najbližje, ko pa jim ti ne morejo pomagati, pa poiščejo tudi strokovne službe (Vilič Klenovšek, 1999).

Za opis raznolikosti profilov in vloge strokovnjakov, ki delujejo na področju svetovalnega dela, lahko uporabimo tudi prispodobo angle-

\section{Posameznik v izobraževanju pogosto potrebuje pomoč, nasvet, informacijo.} škega strokovnjaka Raya Woolfa, ki je raznoliko paleto ljudi, ki sodelujejo v svetovalnem delu, označil kot komet (Woolfe, 1997: 520). V konici kometa so plačani svetovalci, ki se ukvarjajo s strokovnimi vprašanji, povezanimi s svetovalnim delom, in so v celoti predani temu delu ter imajo tudi dostop do ustreznih strokovnih virov. Ti se povezujejo s prostovoljnimi svetovalci, ki tvorijo naslednji, širši del kometa. Prostovoljci ohranjajo pomembno poslanstvo svetovalnega dela, to je prispevek k družbenim spremembam, saj so za svetovalno delo osebno zavzeti in niso omejeni s plačilom. Med obema deloma kometa je precejšnja prehodnost, povezanost, saj lahko prostovoljci s svojim delom tudi kaj zaslužijo, po drugi strani pa tudi plačani svetovalci pogosto delajo prostovoljsko. Pomemben pa je tudi rep kometa, ki ga tvori veliko število različnih ljudi vseh strok, na katere vplivajo vrednote, teorija in poslanstvo ter metode svetovalnega dela. Vse to vključujejo v svoje druge vloge, ki jih opravljajo, in pri katerih uporabljajo veščine svetovanja in nasvetovanja na različnih področjih - v izobraževanju (kot učitelji, organizatorji izobraževanja, mentorji, tutorji ipd.), zdravstvu (npr. medicinske sestre, zdravniki), socialnem delu, upravljanju in vodenju organizacij, v pravnih službah ter tudi marsikje drugje.
Ugotovimo lahko, da je tudi v Sloveniji na področju andragoškega svetovalnega dela podobno. Manjše število strokovnjakov je zaposlenih kot svetovalcev (večinoma v svetovalnih središčih za izobraževanje odraslih - ISIO), nekateri delujejo kot prostovoljci, največje število ljudi pa veščine svetovanja uporablja vsakodnevno ali le občasno, vendar se ne imenujejo svetovalci. Naj poudarim, da so lahko njihove vloge $\mathrm{v}$ izobraževalnem procesu povsem različne, enako pa se lahko razlikuje tudi njihov način dela $v$ procesu pomoči odraslim pri izobraževanju; ta raznolikost je zaželena in pomembna, saj s tem omogočajo odraslim, ki potrebujejo informacije ali pomoč pri izobraževanju, kar najbolj pestro podporo. Seveda nikakor ne moremo pričakovati, da bi lahko npr. učitelji in organizatorji izobraževanja odraslih ponudili vso svetovalno pomoč, ki jo odrasli potrebujejo, in da svetovalcev zato ne potrebujemo. Najzahtevnejšo zvrst andragoškega svetovalnega dela - svetovanje - lahko ustrezno izvajajo le za to usposobljeni svetovalci, saj za kakovostno svetovanje potrebujemo posebne pogoje in posebno strokovnost. Po drugi strani pa menim, da je v Sloveniji še veliko prostora tudi za različne oblike prostovoljskega udejstvovanja na področju andragoškega svetovalnega dela, ki ga bo treba v prihodnosti krepiti, zato bomo morali tudi drugim strokovnjakom, ki se tako ali drugače srečujejo s svetovalnim delom, možnosti andragoškega svetovalnega dela bolj približati.

Podatki raziskave ALPINE (2008: 76-77) kažejo, da imajo - v večini v raziskavo vključenih držav ${ }^{2}$ - na področju izobraževanja odraslih andragoške svetovalce, ki opravljajo različne vrste svetovalnega dela. Po drugi strani v njej tudi ugotavljajo, da mnogi učitelji v okviru poučevanja in mentorske oz. tutorske vloge uporabljajo svetovalne veščine, česar pa obratno ne moremo trditi: tisti, ki so zaposleni kot svetovalci, namreč le redko opravljajo tudi druge vloge, npr. poučujejo. Potrdimo torej lahko, da je vloga svetovalca dokaj specifična 
in zahteva celega človeka, ki je za svetovanje tudi ustrezno usposobljen.

Andragoški delavci, ki niso svetovalci, temveč pri svojem delu z odraslimi le uporabljajo veščine svetovanja, so lahko zelo pomemben člen pri zagotavljanju pomoči odraslim. Ne le, da lahko odraslim sami ponudijo nekatere vrste pomoči v procesu učenja in izobraževanja (morda le informacijo ali nasvet), izredno pomembno je tudi, da dovolj dobro poznajo možnosti, ki so odraslim na voljo v »specializiranih« središčih za andragoško svetovalno delo (ISIO, v prihodnosti morda tudi druga središča), in da sami prepoznavajo pomen pravočasne, ustrezne in vseobsegajoče svetovalne pomoči odraslim udeležencem izobraževanja. V procesu izobraževanja lahko odraslega spodbudijo, da se obrne na svetovalca, lahko mu tudi predstavijo, kakšne vrste pomoči lahko v središču dobi. Udeleženci izobraževanja učiteljem, organizatorjem izobraževanja, mentorjem ali tutorjem pogosto zelo zaupajo in upoštevajo njihovo mnenje, ki je v tem primeru zelo pomembno. Prav zato bi morali dejavnosti andragoškega svetovalnega dela dobro poznati vsi, ki sodelujejo v procesu izobraževanja odraslih.

\section{ANDRAGOŠKO SVETOVALNO DELO - VEZNI ČLEN V IZOBRAŽEVANJU ODRASLIH}

Posameznik, ki se odloča za izobraževanje, v tem procesu pogosto potrebuje pomoč, nasvet, informacijo. Po eni strani se $-\mathrm{z}$ družbenimi vplivi, ki poudarjajo odgovornost posameznika za lastno izobraževanje - povečujejo potrebe po stalnem izobraževanju, ki jih narekujejo hiter tehnološki razvoj, zahteve dela in življenja nasploh, vplivi globalizacije, spreminjanje družbenih sistemov, demografske spremembe itd., po drugi strani pa se povečujejo tudi pestrost ponudbe in možnosti izobraževanja odraslih. Posameznik se mora vse pogosteje sam odločati, kakšno izobraževanje bi bilo zanj ustrezno, v katero organizacijo naj se vključi, kako naj poteka njegovo izobraževanje, da bo lahko dosegel zastavljene cilje. Ponudnikov izobraževanja je vse več in $\mathrm{v}$ tem procesu izbire in odločitve za izobraževanje je andragoško svetovalno delo izredno pomemben člen, posrednik ali informator, ki ga P. Cross (1978) poimenuje kar »manjkajoči vezni člen" ali »missing link « v sistemu izobraževanja odraslih, seveda zato, ker odrasli te možnosti pogosto nimajo. Brez tega člena je dostop odraslih do raznolikih možnosti izobraževanja pogosto otežen, kar marsikoga že pred vključitvijo v izobraževanje odvrne od nadaljnjih korakov, ki bi vodili k udeležbi. Seveda pa je andragoško svetovalno delo izredno pomembno tudi med samim izobraževanjem, še zlasti pri odraslih, ki se dlje časa niso izobraževali ali pa imajo pri učenju različne težave. Nekateri bodoči udeleženci izobraževanja bodo pomoč poiskali sami, medtem ko bodo drugi pri odločitvi potrebovali več spodbude, naj bo od prijateljev, učiteljev ali drugih strokovnih delavcev. Pri tem je izredno pomembno, da je možnosti, kjer pomoč lahko dobimo, več in da je dostopna na različnih mestih.

Dejavnosti andragoškega svetovalnega dela so neke vrste posrednik med individualnimi in družbenimi potrebami. Watts (1996a: 381) ugotavlja, da se te svetovalne dejavnosti razvijajo skladno z dvema ciljema. Prvi cilj, ki mu sledijo vlade pri podpori razvoju dejavnosti andragoškega svetovalnega dela, je ekonomska učinkovitost. Svetovalno delo, povezano z izobraževanjem, je dejavnik, ki povezuje izobraževalni sistem s trgom dela in tako optimizira ekonomske koristi glede na državna vlaganja v izobraževanje. Vendar pa ima razvoj svetovalnih dejavnosti še drug velik cilj, in sicer povečevanje družbene enakosti pri dostopu do izobraževalnih in poklicnih možnosti. Andragoško svetovalno delo ima namreč lahko zelo pomembno vlogo pri povečevanju pričakovanj posameznikov iz deprivilegiranih skupin, ko jih ozavešča o izobraževalnih 
in drugih možnostih in jim pomaga pri dostopanju do njih. Razmerje med enim in drugim ciljem je $\mathrm{v}$ različnih središčih za svetovalno delo zelo različno, odvisno pa je tudi od drugih dejavnikov (npr. političnega sistema, stopnje demokratizacije in ekonomskega razvoja v družbi, od sistema izobraževanja in zaposlovanja, socialnih in kulturnih dejavnikov itd.). $\mathrm{O}$ razmerju med individualiziranimi in bolj družbeno naravnanimi cilji ter posledično tudi med pristopi v svetovalnem delu se sicer ta čas razvija kar intenzivna razprava (Usher, Edwards, 2005; Watts 1996b idr.).

Farmer (v Palmer, 1997) razvoj svetovalnih dejavnosti na področju izobraževanja odraslih umesti v tri obdobja oz. tri perspektive, ki nastanek in pojavnost svetovalnega dela različno opredeljujejo. V 50. letih prejšnjega stoletja so izobraževalne ustanove začenjale ponujati zlasti informiranje in nasvetovanje za udeležence svojih programov. To najožjo perspektivo bi lahko poimenovali $\mathrm{v}$ institucijo osredinjeni pogled, saj jo označuje prepričanje, da gre pri andragoškem svetovalnem delu za dejavnost, ki jo izvajajo strokovno usposobljene osebe - svetovalci, ki jih zaposluje organizacija ali agencija za izobraževanje odraslih. Drugačen pogled na svetovalno delo se je pojavil v 70. letih, predvsem zaradi kritike, da je svetovalno delo bolj v funkciji izobraževalnih ustanov (in njihovih želja po pridobivanju in ohranjanju udeležencev) kot pa posameznika. Novi pristop zagovarja večji dostop odraslih do andragoškega svetovalnega dela, kar naj bi zagotovili s svetovalnimi dejavnostmi, ki se odzivajo na resnične potrebe udeležencev v zvezi z učenjem. Svetovalne dejavnosti izvajajo različni strokovnjaki in prostovoljci, ki so bodisi zaposleni v izobraževalni organizaciji bodisi prihajajo od drugod, tako da lahko del svetovalne pomoči ponujajo tudi učitelji, knjižničarji, mentorji, prostovoljci in drugo osebje. Andragoško svetovalno delo lahko skladno s to perspektivo poteka na različnih mestih, v različnih ustanovah, npr. v skupnostnih organizacijah, knjižnici, športnih središčih, delovnih organizacijah itd. Tak, odprt model andragoškega svetovalnega dela je nagovarjal tudi ranljive skupine odraslih, ki se $\mathrm{v}$ tradicionalne izobraževalne ustanove ne vključujejo. Tretjo, najširšo perspektivo pa bi lahko poimenovali tudi situacijski pristop, saj svetovalno delo opredeljuje kot dejavnosti, ki so izrazito prilagojene posamezniku, njegovim potrebam in težavam. Gre predvsem za individualne storitve, ki odgovarjajo potrebam posameznih skupin (npr. manj izobraženim odraslim, starejšim, priseljencem itd.). Ta pristop je nastal skladno z ideologijo, ki poudarja individualizem in zagovarja individualno odgovornost posameznika za lasten razvoj.

Podobno je o možnostih razvoja andragoške svetovalne dejavnosti razmišljala V. Rivis (1992) in ga opredelila v okviru treh pojavnih oblik, ki zadovoljujejo različne potrebe odraslih po svetovalni pomoči: svetovalno delo kot pomoč pri zaposlovanju, svetovalno delo kot pomoč pri izobraževanju in neodvisno svetovalno delo za učenje.

Pri svetovalnem delu, ki je namenjeno zaposlovanju, so v ospredju ekonomski cilji; ta svetovalna dejavnost se, če gre za zaposlene, lahko financira tudi s prispevki svetovancev. To obliko izvajajo službe za razvoj kariere, zasebniki in druge ustanove. Bolj se podpirajo gospodarsko dejavni posamezniki kot skupine; manj je povezovanja $\mathrm{z}$ drugimi ponudniki svetovalnih dejavnosti. Prioritete so posledica vpliva neoliberalne politike, ki v ospredje postavlja pomen vseživljenjskega izobraževanja za boljšo konkurenčnost delovne sile, njeno prožnost in prilagodljivost.

Svetovalno delo kot pomoč pri izobraževanju vodijo izobraževalne ustanove za svoje potrebe, izvajajo pa ga zaposleni na teh ustanovah. Prednost imajo udeleženci in bodoči udeleženci izobraževalnih programov ustanove, ki ponuja tudi svetovanje, da bi udeležencem omogočila boljše učne dosežke; gre zlasti za pomoč posameznikom pri njihovem izobra- 
ževanju, manj pomoči se zagotavlja ranljivim skupinam odraslih. Dosežki svetovalnega dela se ocenjujejo in so podvrženi trženju, kar vodi k izgubi nepristranskosti. V Sloveniji takšno svetovalno dejavnost izvajajo različne izobraževalne ustanove za lastne potrebe. ${ }^{3}$ Kot ugotavlja tudi Rivisova (Rivis,1992), je za to svetovalno delo značilno, da je »tržno « naravnano, da torej vključuje predvsem tisto informiranje in nasvetovanje, ki bo pripomoglo k boljšemu vpisu v izobraževalne programe in uspešno dokončanje začetega izobraževanja.

Kot tretja zelo pomembna vzporedna možnost naj bi se razvijalo tudi t. i. neodvisno andragoško svetovalno delo, ki sodi $\mathrm{v}$ dejavnosti lokalnih skupnosti in prostovoljskega sektorja. Takšno svetovalno delo se pretežno financira iz sredstev lokalnega proračuna (občine) in s sredstvi različnih drugih lokalnih organizacij. Ta svetovalna dejavnost zadovoljuje raznolike zahteve učečih se, podpira različna izobraževalna in prostovoljska omrežja ter se povezuje z njimi. Namenjeno je učečim se odraslim vseh starosti, še posebno pa izobrazbeno zapostavljenim in drugim ranljivim skupinam, ki se samoiniciativno ne vključujejo $\mathrm{v}$ javne in zasebne izobraževalne organizacije. Neodvisno andragoško svetovalno delo je pogosto na obrobju skrbi uradnih sistemov izobraževanja in usposabljanja, zato ga ogrožajo politične spremembe in pomanjkanje finančnih sredstev ter nestalno financiranje. Aktivno razvija vse zvrsti andragoškega svetovalnega dela.

V evropskih državah je najbolj izrazito razhajanje med svetovalnim delom za poklic in zaposlitev in andragoškim svetovalnim delom, namenjenim odraslim, ki potrebujejo celostno pomoč (na področju izobraževanja, osebnega razvoja in pri razvoju poklicne poti) (Jelenc Krašovec, 2009). V trenutni politiki lahko zaznamo večjo naklonjenost ekonomski učinkovitosti, zaradi česar je tudi v Sloveniji (podobno kot $\mathrm{v}$ mnogih evropskih državah) ${ }^{6}$ v ospredju svetovalno delo za poklic in zaposlitev, ki ga v okviru svojih pristojnosti izvaja zavod za zaposlovanje. To pomeni, da bo treba s strokovnimi argumenti še intenzivneje dokazovati, da odrasli za uspešno doseganje svojih raznolikih ciljev potrebujejo tudi »neodvisno« andragoško svetovalno delo.

Da je dejavnosti svetovalnega dela nemogoče zožiti le na svetovalne dejavnosti, povezane $\mathrm{z}$ delom in zaposlitvijo, bom na kratko predstavila v poglavju o zvrsteh, ciljih in funkcijah andragoškega svetovalnega dela, ki kažejo na veliko raznovrstnost možnosti pri odzivu na potrebe odraslih.

Neodvisno andragoško svetovalno delo je izredno pomemben člen v celotni ponudbi andragoških svetovalnih dejavnosti, saj gre za svetovalne možnosti $\mathrm{z}$ večjo socialno občutljivostjo za ranljive skupine odraslih. ${ }^{4} \mathrm{~V}$ nasprotju z drugima dvema možnostima, ki sta namenjeni konkretnim ciljnim skupinah odraslih (bodisi zaposlenim bodisi tistim, ki se vključujejo v konkretno izobraževalno ustanovo), nagovarja vse ljudi, ki živijo v neki skupnosti. Izhaja iz njihovih potreb in se nanje tudi odziva. ${ }^{5}$ Za ustrezen razvoj neodvisnega andragoškega svetovalnega dela bo treba povečati kohezivnost skupnosti, podpreti razvoj različnih skupnostnih dejavnosti in okrepiti zavest o pomenu prostovoljstva tudi na področju svetovalnih dejavnosti. Zlasti za povečevanje družbene vključenosti obrobnih skupin odraslih je nujno potreben razvoj svetovalnih dejavnosti za izobraževanje čim bliže kraju, kjer ljudje živijo. Čeprav je model Riviseve nastal že pred časom, lahko ugotovimo, da je - ravno zaradi vpliva politike - neodvisno andragoško svetovalno delo premalo razvito in zapostavljeno, zato bi si zaslužilo več pozornosti stroke in javnosti. Tako bi se tudi nekoliko približali vsem obljubam in napovedim, ki jih lahko izluščimo iz najrazličnejših nacionalnih in evropskih političnih dokumentov in strategij. 


\section{ZVRSTI, CILJI IN FUINKCIJE ANDRAGOŠKEGA SVETOVALNEGA DELA}

Odrasli, ki potrebujejo pomoč pri izobraževanju, lahko v procesu svetovalnega dela dobijo različne možnosti pomoči, ki jih opredelimo kot tri zvrsti: informiranje, nasvetovanje in svetovanje. Vsaka nadaljnja zvrst je bolj strukturirana, bolj zahtevna in celostna, poleg tega pa vsaka nadaljnja vključuje tudi predhodno zvrst (Jelenc Krašovec, Jelenc, 2003). Vsako od zvrsti lahko uporabljamo posamično ali kombinirano, hkrati pa tudi nekatere druge dejavnosti oz. ukrepe, s katerimi svetovancu pomagamo reševati številna praktična vprašanja, povezana $z$ učenjem in izobraževanjem.

Med informiranjem in nasvetovanjem je pomembna razlika; prvo pomeni le dajanje ali posredovanje ustrezne informacije, drugo pa »poleg dajanja ali posredovanja informacij in podatkov vključuje tudi razlago in/ali ustrezna pojasnila, s katerimi pomagamo osebi, da reši svoj problem« (Jelenc Krašovec, Jelenc, 2003: 51). Dajanje nasvetov označuje vplivanje svetovalca, ki s svojim znanjem in izkušnjami ter z uporabo informacij in pojasnil svetovancu olajša odločanje in mu pomaga rešiti njegov problem (Burnard, 1999: 24). Gre za precej direktivne dejavnosti, ki v manjši meri dopuščajo samoiniciativnost svetovanca.

Pri svetovanju, najzahtevnejši in najbolj nedirektivni izmed vseh zvrsti svetovalnega dela, gre za strokovno zahteven in nemalokrat zapleten proces, ki terja bolj poglobljen pristop, navadno traja dalj časa in zahteva stalno medsebojno interakcijo ter odnos med svetovalcem in svetovancem. Gre za celovit in sestavljen proces, kjer svetovalec in svetovanec večinoma skupaj oblikujeta proces pomoči, pri čemer je svetovalec - s svojim znanjem in izkušnjami - pospeševalec posameznikovega razvoja in spreminjanja ter razumevanja celotnega procesa učenja. »Vloga svetovanja je spodbujati takšno delovanje svetovanca, ki je v skladu z njegovimi vrednotami, osebnimi zmožnostmi in sposobnostmi za samostojno odločanje.« (Howard, 1996: 24.) Svetovanje je torej »posebna in zahtevnejša zvrst svetovalnega dela, pri kateri se srečujeta dve osebi, svetovalec in svetovanec, s ciljem, da se s povečevanjem zmožnosti svetovanca uspešneje rešujejo njegovi problemi « (Jelenc Krašovec, Jelenc 2003: 142).

Svetovanje kot strokovno zahteven proces lahko vodi le ustrezno usposobljen svetovalec in zato običajno poteka $\mathrm{v}$ organizaciji, kjer so za to tudi ustrezne razmere. Informacije in nasvete o izobraževalnih možnostih pa lahko daje tudi oseba, ki ni posebej usposobljena za svetovanje, kar pomeni, da informiranje in nasvetovanje načeloma lahko izvajajo različni andragoški delavci, pa tudi prostovoljci, ki so dobro seznanjeni s ponudbo, možnostmi in potekom izobraževanja. Informiranje in nasvetovanje lahko poteka na različnih mestih, vsekakor pa čim bliže mestom vsakdanjih dejavnosti ljudi.

Temeljni namen in cilj svetovalnega dela na področju izobraževanja odraslih je čim večjemu številu ljudi pomagati pri uspešnem učenju in izobraževanju. Seveda pa se andragoški svetovalec pri svetovanju kot najzahtevnejši zvrsti andragoške svetovalne dejavnosti slej ko prej dotakne tudi dveh podrejenih ali vzporednih ciljev pomoči: optimalnega osebnostnega razvoja in osebne življenjske poti posameznika ter pomoči pri uresničevanju svetovančevega poklicnega ali delovnega cilja ali poklicne poti. Ti cilji obsegajo področja, kot so motivi in vrednote, zaupanje vase in samopodoba; načini izbiranja možnosti in priložnosti za izobraževanje; določanje in izpeljava strategij za učenje; organiziranje dejavnosti za izpeljavo izobraževanja in učenja; načini in strategije učinkovitega učenja; razvijanje in krepitev sposobnosti za učenje; uveljavitev načinov za ugotavljanje in potrjevanje neformalno in s samostojnim učenjem 
pridobljenega znanja; možnosti in tehnike samoevalvacije $\mathrm{v}$ zvezi $\mathrm{z}$ izobraževanjem in učenjem itn. Andragoško svetovalno delo torej ni namenjeno le enemu ozkemu cilju, temveč se stika tudi z drugimi področji pomoči posamezniku ali pa jih deloma tudi vključuje $v$ svoj koncept in načine pomoči posamezniku, pravo intenzivnost poseganja na druga področja pa svetovalec ugotovi po diagnosticiranju potreb po svetovalni pomoči (Jelenc Krašovec, Jelenc, 2003: 73). Poudariti pa je treba, da naj bi svetovalec razvil čim večjo občutljivost za razumevanje ciljev, ki si jih postavi tudi svetovanec sam. Svetovalci se - glede na svojo teoretsko naravnanost - nagibajo k bolj ali manj natančno zastavljenim ciljem v svetovalnem procesu, vendar pa naj bi ob tem ne pozabili na potrebe in želje svetovancev glede njihovih notranjih ciljev (to so cilji, nad katerimi ima svetovanec neposreden nadzor - misli, občutki, vedenje) in zunanjih ciljev (nad katerimi bi svetovanci radi imeli nadzor, npr. vedenje, občutki in misli drugih ljudi v njihovi okolici) (Dryden, 2006: 65). $\mathrm{Na}$ podlagi ciljev se nato postavijo naloge, ki nastajajo $\mathrm{v}$ procesu refleksije svetovalca in svetovanca ter s katerimi se dosegajo cilji. To je pomemben del procesa svetovanja, ki zahteva čas in stalno vrednotenje izvajanja dogovorjenih nalog (Dryden, 2006: 80, 81).

$\mathrm{Z}$ andragoškim svetovalnim delom naj bi zadovoljevali različne potrebe odraslih po izobraževanju in ima torej več funkcij: posamezniku pomagati pri spoznavanju sebe/osebnih značilnosti, svojih interesov in sposobnosti, učnih navad in motivacije; seznanjanje s ponudbo izobraževanja; pomoč pri določanju in udejanjanju ciljev, povezanih z izobraževanjem ter osebno in poklicno potjo; pomoč pri izobraževanju in učenju ter reševanju problemov, ki se ob tem pojavljajo; odstranjevanje in blažitev različnih ovir, ki se pojavljajo ob izobraževanju ali nameri po izobraževanju (situacijske, institucijske in dispozicijske ovire); pomoč pri uporabi učne in izobraževalne tehnologi- je in razvijanje metod in tehnik učinkovitega učenja; pomoč pri dokazovanju neformalno pridobljenega znanja; spremljanje uspešnosti odraslega pri uresničevanju zastavljenih ciljev. Te funkcije se uresničujejo tudi glede na to, kakšen je problem, ki ga ima svetovanec pri svojem učenju in/ali izobraževanju. Odrasli lahko potrebujejo pomoč pri vključevanju $\mathrm{v}$ izobraževanje, pri organiziranju izobraževanja ali pa pomoč pri učenju in izpeljavi učenja. Če upoštevamo časovno točko, lahko odrasli potrebujejo pomoč pred vključitvijo v izobraževalni program, med izobraževanjem in ob koncu izobraževanja ali med učenjem in po njem. Potrebe odraslih po svetovalni pomoči so torej zelo raznolike, kar pomeni, da so različne tudi ciljne skupine odraslih, ki bodo tako pomoč potrebovale.

Iz raznolikih ciljev in funkcij andragoškega svetovalnega dela je razvidno, da niso vsi enako zahtevni; nekatere od ciljev lahko ob svojem delu uresničujejo tudi drugi andragoški delavci, strokovnjaki, večino pa le ustrezno usposobljeni svetovalci, ki delujejo v svetovalnih središčih. Če je svetovančev problem enostavno rešljiv, zadošča informiranje ali nasvet; vendar pa se tudi za navidezno enostavnimi vprašanji pogosto skriva bolj kompleksen problem, ki zahteva daljšo in bolj poglobljeno pomoč, ki jo lahko ponudi le svetovalec. Navidezno enostavna vprašanja, kot so, ali naj se naprej izobražujem, v kateri smeri, kako uspešno bo moje učenje in izobraževanje, so povezana z odgovori na nekaj drugih vprašanj, denimo, ali imam za to ustrezne sposobnosti, navade, voljo, kako mi bo pri tem pomagala moja izobraževalna preteklost, moje skrbi ob tem, kako me bodo poprejšnje izkušnje pri učenju in izobraževanju ovirale ali motivirale, kaj pričakujem od novega izobraževanja, kakšna je moja samopodoba itn. Globino problema lahko običajno ugotovimo šele po bolj poglobljenem pogovoru $\mathrm{v}$ svetovalnem središču in po potrebi tudi z ustreznimi diagnostičnimi postopki. 


\section{UGOTAVLJANJE POTREB PO SVETOVALNEM DELU V IZOBRAŽEVANJU ODRASLIH}

Odrasli se na andragoškega svetovalca v svetovalnem središču največkrat obrnejo z vprašanji oz. problemi, ki jih lahko rešimo $\mathrm{z}$ informiranjem ali nasvetom, pri čemer praviloma ni treba načrtovati daljše obravnave. Kadar pa gre za zahtevnejše probleme, ki zahtevajo daljši, bolj organiziran postopek svetovalne pomoči, bi bilo neodgovorno, če bi svetovalec svetovancu poskušal pomagati, ne da bi temeljito proučil problem, zaradi katerega svetovanec išče pomoč.

Fazo ugotavljanja in zbiranja podatkov o osebi in bolj poglobljenega seznanjanja s problemom, ki ga ima svetovanec, opredeljujemo kot fazo diagnosticiranja. Svetovalec ta proces vodi zato, da bi čim bolje in jasno

Potrebe odraslih po svetovalni pomoči so zelo raznolike. razumel težave, problem oz. stanje osebe, ki potrebuje pomoč, pri čemer so pomembni tako posameznik (svetovanec) kot tudi okoliščine (širša situacija svetovanca). Ta proces praviloma poteka $\mathrm{v}$ začetnih fazah svetovanja ter je podlaga za nadaljnje odločitve svetovalca in svetovanca glede svetovalne pomoči. $\mathrm{Na}$ podlagi zbranih podatkov se namreč svetovalec in svetovanec pogovorita o svetovančevih problemih, o razhajanju med zdajšnjo in zaželeno situacijo, ovrednotita konflikte oz. ovire pri udejanjanju ciljev, želja in potreb ter se dogovorita o nadaljnjih ukrepih.

Faze svetovalnega postopka različni avtorji različno poimenujejo, vendar gre $\mathrm{v}$ bistvu pri vseh za graditev svetovalnega procesa od faze preučitve problemske situacije, prek faze razvijanja/usklajevanja načrtovanih ukrepov do faze, kjer gre za doseganje zastavljenega cilja (npr. Egan, 1994; Doyle, 1992). Tudi Z. Jelenc (1980: 32-34) proces svetovalnega postopka razdeli v več faz. Prva faza obsega vzpostavitev stika svetovalca s svetovancem in ustvarjanje vzdušja zaupanja, okvirni opis problema, kot ga doživlja in razume svetovanec, podatke o preteklih načinih reševanja problema idr. V tej fazi je pomembno, da svetovanec začuti željo in/ali potrebo po tem, da bi se s svetovalcem še srečal. Druga faza je namenjena pridobivanju podatkov in ocenjevanju problema, kjer svetovalec pridobiva potrebne dodatne podatke o nastanku in razvoju problema, ugotavlja značilnosti svetovanca in okoliščine njegove življenjske poti ter zdajšnjega položaja, pri tem pa lahko uporablja ustrezni instrumentarij. Tretja faza že pomeni proces reševanja problema, saj gre za oblikovanje sklepov, odločanje in ukrepanje, kar naj bi pripomoglo k ublažitvi in odpravljanju svetovančevega problema. Svetovanec lahko na tej podlagi sprejme ustrezne odločitve ter ukrepa skladno s tem, pri čemer mu lahko pomaga tudi svetovalec. V četrti fazi, ki pravzaprav poteka skozi celoten proces svetovanja, svetovalec in svetovanec spremljata učinke svetovanja. Svetovalni proces se ne konča s sprejemanjem odločitev, temveč lahko vrednotenje učinkov poteka tudi po preteku kontinuiranega svetovalnega procesa.

Egan proces pomoči zastavi kot serijo treh hierarhičnih faz, ki svetovalca po korakih vodijo pri izpeljevanju svetovalnega procesa: prva faza je preučitev problemske situacije in neizrabljenih možnosti, druga razvijanje izbranega scenarija, ki ga spremljata novo razumevanje in oblikovanje alternativ za reševanje problema, tretja pa doseganje cilja (Egan, 1994: 25-40). Diagnosticiranje je vključeno v prvo fazo modela pomoči, ki je faza preučevanja problemske situacije. V tej fazi je izredno pomembno, da se vzpostavi odnos zaupanja in medsebojnega sprejemanja med svetovalcem in svetovancem do take mere, da je slednji pripravljen povedati svojo zgodbo in razkriti svoje težave oz. strahove, na podlagi česar bo mogoče nadaljevanje procesa pomoči. Gre za fazo preučevanja, razčiščevanja in ovrednotenja problemske situacije, ki jo spremlja stalno učenje o tem, kaj je doslej šlo narobe, katerih virov oseba še ni uporabila, katere možnosti 
so še neizkoriščene (Egan, 1994: 143). Tudi $\mathrm{v}$ tem modelu fazi diagnosticiranja oz. ugotavljanja problemske situacije sledijo faze reševanja problemov. Doyle pa pravi, da se faze v svetovalnem procesu med seboj prepletajo, se »naravno razvijajo, zato so prehodne, se prekrivajo in so nepretrgane « (Doyle, 1992: 47). Svetovalni proces naj bi bil torej strukturiran; tako so cilji jasnejši in preglednejši, to daje občutek namenskosti in usmerjenosti, omogoča učinkovito porabo časa, ki je na voljo, ter spodbuja sodelovanje med svetovalcem in svetovancem (Lawton, 2008: 39-40).

W. Dryden (2006: 97-113) poudarja, da je na začetku svetovanja izredno pomembno, da se med svetovalcem in svetovancem vzpostavi dober stik, kar je podlaga za ugotavljanje svetovančevih potreb, načrtovanje ciljev in nalog ter zagotavljanje ključnega cilja, da svetovanec bolje razume sebe in druge $\mathrm{z}$ namenom, da bo uspešnejši pri reševanju svojih problemov. $\mathrm{V}$ svetovalnem procesu so uspešnejši bolj usposobljeni svetovalci, ki - poleg teoretskih modelov, skladno s katerimi delujejo - obvladajo komunikacijo, so empatični, poskrbijo za prijeten in strokovno korekten ambient, v katerem potekajo svetovalne dejavnosti, itd. Le taki pristopi zagotovijo, da se poleg kognitivnih pri svetovancu zgodijo tudi čustvene in vedenjske spremembe.

$\mathrm{V}$ prvi fazi svetovalnega procesa, v fazi diagnosticiranja, torej najprej preučimo, kakšne težave ima svetovanec, ki prihaja po pomoč. Če svetovalec oceni, da je problem večji in zahteva daljšo svetovalno pomoč, bo pridobil natančnejše podatke o svetovancu. Pomembno je, da se svetovalec zaveda, da mehanično zbiranje in kopičenje podatkov ni smiselno, zato naj podatke zbira načrtno in selektivno. Seveda je kakovost »diagnoze « močno odvisna tako od načrta kot tudi od njegove izpeljave, zato faza diagnosticiranja od svetovalca zahteva ustrezno znanje, empatičnost in izkušnje. Bentley (2000: 14) nam ponuja možnosti za razmislek, kako bomo načrtovali procese pomoči. Tri ravni opredelitve potreb prikaže v obliki kroga. Pri odzivu na potrebe se lahko osredinimo na potrebe posameznika ali skupine (središče kroga), ki potrebuje podporo, pomoč, priznanje ali sprejemanje. Z oddaljevanjem od središča kroga dosežemo drugo raven, ki se osredinja na proces; s tega izhodišča opredelimo načine in pristope, ki bodo za izbrano skupino ali posameznika najustreznejši pri reševanju problemov ali seznanjanju z izbrano vsebino. Tretja raven pa je načrtovanje vsebine; gre za potrebe po znanju, ki so $\mathrm{v}$ procesu pomoči in rasti pomembne za izbrano skupino ali posameznika. Pri tem lahko potrebe ugotavljamo bodisi tako, da izhajamo iz vsebine, ki je za posameznika/skupino pomembna (in se hkrati sprašujemo, kako vsebino najustrezneje približati svetovancem in kakšen vpliv bo končno imela na nas, na svetovance ali skupino), lahko pa se - nasprotno - predvsem posvetimo posamezniku in njegovim potrebam, šele $\mathrm{v}$ naslednji točki pa nas zanimata proces in vsebina, ki jo $\mathrm{v}$ tem primeru prilagodimo potrebam posameznika ali skupine.

Pri diagnosticiranju lahko uporabljamo različne strokovne pripomočke ali diagnostične instrumente, ki jih skupaj označujemo z izrazom diagnostični instrumentarij. Stroke se precej razlikujejo po tem, kako bogat instrumentarij imajo na voljo pri diagnosticiranju, in andragogika, ki je sorazmerno mlada veda, se s temi vprašanji zdaj intenzivneje ukvarja. $Z$ vidika andragoškega svetovalnega dela nas zanimajo predvsem pripomočki in instrumenti, ki nam omogočajo ugotovitev in ocenitev tistih svetovančevih problemov in vprašanj, ki so povezani z njegovim izobraževanjem in učenjem (Jelenc Krašovec, Jelenc, 2003: 198), andragoškega svetovalca bodo seveda zanimala predvsem vprašanja, ki so tako ali drugače povezana s področjem izobraževanja. Glede učenja ga bodo zanimale predvsem značilnosti svetovančevega učenja v preteklosti in zdaj, njegove sposobnosti in pripravljenost za (sa- 
mostojno) učenje, morda tudi učni stil. Ugotavljal bo, kakšen je svetovančev obseg znanja ter vsebina in kakovost znanja; ugotavljal bo svetovančeve interese na področju učenja in izobraževanja, na področju prostočasnih dejavnosti ter na področju poklicnega dela in zaposlitve. Morda bo želel ugotoviti svetovančevo vedenje v različnih učnih situacijah (pripravljenost za učenje in izobraževanje, pripravljenost za samostojno učenje, učne navade in učno zmogljivost). Ne nazadnje pa je z izobraževanjem povezan tudi razvoj kariere (razvoj osebne in življenjske poti, razvoj poklicne poti in pričakovanja na obeh navedenih področjih). Andragoški diagnostični instrumentarij torej vključuje sheme za opazovanje, sheme za diagnostični pogovor, vprašalnike, inventarje ali popisne pole, teste. Sheme so instrumenti ali pripomočki, ki nam omogočajo pridobitev relevantnih podatkov za nadaljnje odločanje o reševanju problema. Svetovalec na začetku okvirno določi strukturo dejavnikov, ki jih mora ugotoviti, seznam in načrt vprašanj, ki jih želi postaviti svetovancu, in njihov okvirni vrstni red. Sheme, ki jih po tem načrtu uporablja, pa so nekakšni opomniki, s katerimi si pomaga pri sistematizaciji diagnostičnega postopka. Svetovalec lahko pri diagnosticiranju uporablja tudi različne teste, npr. teste spretnosti, interesne teste, teste, s katerimi ugotavlja raven že usvojenega znanja, pripravljenost za nadaljnje učenje ipd. Seveda andragoški svetovalec ne more uporabljati različnih psiholoških testov, lahko pa za te potrebe v svetovalni postopek vključi psihologa ali pa svetovanca napoti v ustrezno ustanovo. Na andragoškem področju so teoretiki in praktiki v zadnjih letih za potrebe diagnosticiranja $\mathrm{v}$ svetovalnem delu razvili kar nekaj vprašalnikov, s katerimi lahko ugotavljamo prevladujoč učni stil, stile spoznavanja, pripravljenost za samostojno učenje, interese ipd. (glej npr. Jelenc Krašovec et al., 2007).

Za določanje temeljne vsebine svetovalne pomoči lahko uporabimo enotno shemo obrav- nave (več v knjigi Jelenc Krašovec, Jelenc, 2003: 210-217), ki ponazarja celostnost postopka obravnave glede na raznolikost problemov, zaradi katerih prihajajo svetovanci v svetovalno središče. Shema vključuje dve fazi. V prvi, diagnostični fazi gre za presojo svetovalnega primera, pri čemer lahko uporabimo več postopkov: selektivno uporabimo shemo za diagnostično eksploracijo, presodimo o vključitvi drugih strokovnjakov v obravnavo, izberemo diagnostični instrumentarij, premislimo o vključitvi drugih ustanov v obravnavo, ocenimo posameznikove močne in šibke točke, kar je pomembno za odločitev o nadaljnjih oblikah svetovalne pomoči. V drugi fazi gre za odločitev o načinih svetovalne pomoči, kjer se odločamo o temeljni vrsti pomoči (izbiramo med informiranjem, nasvetovanje in svetovanjem), vsebini pomoči (izobraževanje/učenje, poklic, osebnostni razvoj) in poteku oz. metodah svetovalne pomoči (direktivno/nedirektivno, krajše/daljše, individualno/skupinsko svetovanje ali samousmerjanje).

\section{ZAKLJUČEK}

Andragoško svetovalno delo v taki ali drugačni obliki je $v$ današnjem sistemu izobraževanja odraslih nepogrešljiv člen, ki učečim se odraslim pomaga pri uresničevanju ciljev, povezanih z učenjem in izobraževanjem. Tudi za andragoško svetovalno delo velja - podobno kot za področje izobraževanja odraslih -, da ga določata pestrost in raznolikost, njegov razvoj pa je odvisen od izobraževalne politike in možnosti, da se prizadevanja strokovnjakov glede njegovega razvoja uresničujejo. Izredno pomemben dejavnik so vsi strokovnjaki, ki sodelujejo v procesu pomoči odraslim pri učenju. Boljše kot je njihovo zavedanje o pomenu dejavnosti andragoškega svetovalnega dela, več bodo pripravljeni vlagati v razvoj lastnih znanj in usposobljenosti za kakovostno svetovalno delo z odraslimi. Niso pomembni le svetovalci, ki so za andragoško svetovalno delo posebej 
usposobljeni in je to njihova temeljna dejavnost, temveč vsi andragoški delavci, vključno z organizatorji izobraževanja, učitelji, mentorji, tutorji, strokovnimi sodelavci, knjižničarji in drugimi, ki se z odraslimi udeleženci srečujejo v procesu izobraževanja. Njihova pripravljenost za pomoč, empatičnost in razumevanje, ki temeljijo na ustreznem znanju in osebnostnih lastnostih, so pogosto dejavnik, ki prevesi odločitev odraslega glede njegovega/njenega nadaljnjega izobraževanja. So pomemben člen, ki andragoškim svetovalcem pomagajo pri zagotavljanju večjega dostopa odraslih do izobraževalnih možnosti in uspešnejši izpeljavi in dokončanju njihovega izobraževanja.

\section{VIRI}

ALPINE. (2008). Adult Learning Professions in Europe. A study of the current situation, trends and issues. Final report. Zoetermeer: Research voor Beleid.

Barrot, J. (2008). »Culture and Diversity in Counselling«. V: Dryden, W., Reeves, A. (ur.), Key Issues in Counselling in Action. London, Thousant Oaks, New Delhy, Singapore.

Bentley, T. (2000). Facilitation. Gloucestershire: The Space between Publishing.

Burnard, P. (1999). Practical Counselling and Helping. London, New York: Routledge.

Cross, P. K. (1978). The Missing Link. Connecting Adult Learners to Learning Resources. New York: The Colllege Board.

Doyle, R. E. (1992). Essential Skills and Strategies in the Helping Process. Pacific Grove: Brooks/Cole.

Dryden, W. (2006). Counselling in a nutshell. London, Thousant Oaks, New Delhy: SAGE.

Edwards, R., Armstrong, P., Miller, N. (2001). »Include me out: critical readings of social exclusion, social inclusion and lifelong learning «. International Journal of Lifelong Education, 5: 417-428.

Egan, G. (1994). The Skilled Helper. A Problem-Management Approach to Helping. Pacific Grove: Brooks/Cole Publishing Company.

Foley, G. (2004). »Introduction: The state of adult education and learning«. V: Foley, G. (ur.), Dimensions of Adult Learning. Maldenhead. Berkshire.
Howard, A. (1996). Challenges to Counselling and Psychotherapy. London: Macmillan.

Illeris, K. (2004). The Three Dimensions of Learning. Frederiksberg: Roskilde University Press.

Jelenc Krašovec, S., Jelenc, Z. (2003). Andragoško svetovalno delo. Ljubljana: Filozofska fakulteta.

Jelenc Krašovec, S. (2009). »Andragoško svetovalno delo kot dejavnik spodbujanja družbene vključenosti odraslih«. Andragoška spoznanja, 15: 38-51.

Jelenc Krašovec, S., Knaflič, L., Perme, E., Radovan, M., Rupert, J., Vilič Klenovšek, T., Žalec, N. (2007). Svetovalni pripomočki v izobraževanju odraslih. Ljubljana: Andragoški center Slovenije.

Jelenc, Z. (1980). »Svetovalno delo na področju izobraževanja odraslih«. V: Jelenc, Z. (ur.), Andragoško svetovalno delo (izbrano gradivo za študij). Ljubljana.

Lawton, Barbara (2008). »Structuring the Counselling Process «. V: Dryden, W., Reeves, A. (ur.), Key Issues in Counselling in Action. London, New Delhy, Singapore.

McCarthy, M., Millar, R. (2006). »Career guidance in Northern Ireland: retrospect and prospect «. British Journal of Guidance \& Counselling, 34: 73-91.

Moore, Rob (2004). Education and society. Cambridge: Polity Press.

Palmer, S. (1997). Handbook of Counselling. London, New York: Routledge.

Rivis, V. (1992). Guidance for Adult Learners: The new chalenges. Towards a national strategy. Udace. Neobjavljeno gradivo.

Usher, R., Edwards, R. G. (2005). »Subjects, networks and positions: Thinking educational guidance differently «. British Journal of Guidance \& Counselling, 33: 397-410.

Vilič Klenovšek, T. (1999). »Vloga svetovalnega dela $\mathrm{v}$ izobraževanju odraslih za večjo povezanost in učinkovitost«. Vzgoja in izobraževanje, 3: 37-43.

Watts, A. G. (1996a). »Careers Guidance and public policy«. V: Watts, A. G., Law, B., Killeen, J., Kidd, J. M., Hawthorn, R., Rethinking carees education and guidance. Theory, Policy, Practice. London, New York.

Watts, A. G. (1996b). »Socio-political ideologies in guidance «. V: Watts, A. G., Law, B., Killeen, J., Kidd, J. M., Hawthorn, R., Rethinking carees education and guidance. Theory, Policy, Practice. London, New York. 
Woolfe, R. (1997). »Present Position and Future Prospects «. V: Palmer, S. (ur.), Handbook of Counselling. London, New York.

1 Večina teoretikov na področju svetovalnih dejavnosti meni, da mora biti svetovalec visoko usposobljen praktik (Lawton, 2008: 37).

2 Vključene so bile Belgija, Bolgarija, Danska, Estonija, Finska, Francija, Nemčija, Grčija, Italija, Poljska, Romunija, Slovenija, Portugalska, Švedska in Velika Britanija.

3 Raziskava, ki so jo na Andragoškem centru Slovenije opravili leta 1998 (Vilič Klenovšek, 1999), je pokazala, da tako informiranje in svetovanje v Sloveniji izvajajo npr. srednje šole, ki imajo enoto za izobraževanje odraslih, pa tudi zasebne izobraževalne organizacije.

4 Pri razmisleku o pomenu svetovalnih dejavnosti ne smemo pozabiti tudi na kulturno raznolikost udeležencev, s katero se srečujejo tako izobraževalci odraslih kot tudi svetovalci. Barrot (2008: 271-273) poudarja, da naj bi svetovalci in izobraževalci odraslih razvili občutliivost za različnost, pa naj gre za osebno kulturo posameznika ali pa za kulturno pogojeno znanje in vedenje, oblačenje, izražanje, verska prepričanja in druge značilnosti, $k i$ izvirajo iz drugačnega socio-kulturnega ozadja in lahko ustvarjajo predsodke in stereotipe.

5 Pri razvoju svetovalnih dejavnosti za odrasle velja Severna Irska za primer dobre prakse. Svetovalna središča za izobraževanje odraslih (Educational Guidance Service for Adults - EGSA) so nastala leta 1967 kot eksperimentalni projekt, danes pa so neodvisna neprofitha organizacija, ki deluje v prostovoljskem sektorju, financira pa se z različnimi sredstvi. Središča delujejo na različnih mestih, npr. v skupnostnih centrih, kolidžih in knjižnicah in v omrežje povezujejo različne ponudnike izobraževanja, delodajalce in skupnostne organizacije. Zaradi tega svetovalna središča laže uresničujejo svoje poslanstvo s ciljem, da bi dosegli tiste odrasle, ki sicer ne bi poiskali svetovalne pomoči (McCarty, Millar, 2006).

6 Tudi podatki raziskave ALPINE (2008: 76) kažejo, da se ponudniki svetovalnih storitev v evropskih državah najpogosteje osredinjajo na svetovalno delo za razvoj kariere (zlasti v povezavi z zaposlovanjem), svetovalno delo v povezavi z izobraževalnim procesom (izbira programa in pomoč med izobraževanjem), pomembno pa je tudi svetovalno delo, povezano z osebnimi problemi, ki vplivajo na izobraževanje. Analiza dejavnosti, ki jih izvajajo andragoški svetovalci, pa kaže, da je njihova ključna naloga svetovanje odraslim pri posameznih učnih predmetih/vsebinah, mentorstvo in pomoč pri osebnem razvoju in pomoč v procesu samostojnega učenja. 